\title{
Biotic stress (Insect) of Cucurbits in Arid Region of Rajasthan: A Review
}

\author{
Haldhar $\mathrm{SM}^{1^{*}}$, Samadia $\mathrm{DK}^{1}$ and Choudhary $\mathrm{BR}^{1}$ \\ 1Department of Agricultural Entomology, ICAR-Central Institute for Arid Horticulture, India
}

Submission:May 01, 2018; Published: June 08, 2018

"Corresponding author: Shravan Haldhar M, 1ICAR-Central Institute for Arid Horticulture, Sri Ganganagar Highway, Beechwal Industrial Area, Bikaner-334006, India, E-mail: haldhar80@gmail.com

\begin{abstract}
The cucurbit plants belong to family Cucurbitaceae comprises of about 117 genera and 825 species in warmer parts, in which mateera, muskmelon, ridge gourd, bottle gourd, snapmelon, kachri, round melon, sponge gourd, etc. are found in arid regional of Rajasthan. The main pests of cucurbit crops are fruity fly, Bactrocera cucurbitae, leaf eating caterpillar, Diaphania indica; leaf miner, Liriomyza trifolii; white flies, Bemisia tabaci; Hadda beetle, Epilachna viginctioctopunctata; aphids, Aphis gossypii; ash weevil, Myllocerus subfasciatus; flower beetles Mylabris macilenta; Anthicus crinitus and Anthrenus subclaviger and beet worm, Spodoptera exigua. The cucurbitaceous vegetables are loss the yield ranged from 30-100\% due to pest attack and its depending upon cucurbit species and the season in different parts of arid region.
\end{abstract}

Keywords: Cucurbits; Insect-pest scenario; Biotic stress; Arid region

\section{Introduction}

The vegetable crops belonging to the family Cucurbitaceae are known as cucurbits or gourds. The family Cucurbitaceae containing more or less 117 genera and 825 species in warmer parts of the world [1]. Most of them originated in Old World but many species originated in the New World and seven genera in both the hemispheres. In India, [2] the Cucurbitaceae family contained 36 genera and 100 species of cucumbers. The numbers of cucurbits are cultivated, which share about $5.6 \%$ of the total vegetable production in India. The genetical diversity of cucurbits are considerable range in the monoploid (x) chromosome number including seven (Cucumis sativus), eleven (Citrullus spp., Momordica spp., Lagenaria spp., Sechium spp., and Trichosanthes spp.), twelve (Benincasa hispida, Coccinia cordifolia, Cucumis spp. other than C. sativus, and Praecitrullus fistulosus), thirteen (Luffa spp.), and twenty (Cucurbita spp.) [3-5]. The family is dominantly distributed all around the tropical world where edible fruits were amongst the earliest cultivated plants in both the old and new worlds. This large group of vegetable crops, consisting of more than fifteen kinds, is grown and consumed within the tropical region of the word. They are consumed in various forms of cucurbits crops i.e., salad (cucumber, gherkins, long melon), sweet (ash gourd, pointed gourd), pickles (gherkins), and deserts (melons). It's use is important because of calories, minerals or vitamins since they are generally low to moderate in nutrient with a few exceptions like bitter gourd (rich in vitamin C, 96mg/100g ), pumpkin (vitamin
A, 1600IU/100g), karol (high protein, 3.1/100g), parwal and chow-chow (calcium, 531mg and $140 \mathrm{mg} / 100 \mathrm{~g}$, respectively). From the nutritional point of view, cucurbits seeds are valued for their high oil and protein contents [6-8].

Cucurbits are infested with various insect right from the primordial stages of the crop to harvest of the products. Besides the direct damage, many pests act as vector for viruses [9]. The main pests of cucurbit crops are leaf eating caterpillar, Diaphania indica; fruity fly, Bactrocera cucurbitae (Coquillet); leaf miner, Liriomyza trifolii; white flies, Bemisia tabaci; Hadda beetle, Epilachna viginctioctopunctata (Fabricius); aphids, Aphis gossypii (Glover) and ash weevil, Myllocerus subfasciatus [10]. Three flower beetles were also observed on cucurbits in the arid region and identified as Mylabris macilenta, Anthicus crinitus and Anthrenus subclaviger [11]. For the first time, the beet armyworm was also observed on cucurbits in the hot arid region of north-western India, (i.e., Thar Desert) and identified as Spodoptera exigua [12]. The cucurbit fruit fly (B.cucurbitae Coquillett) has been the most prominent pest over the last several decades in India [13-18]. Depending on the environmental conditions and susceptibility of the crop species, the extent of losses varies between 30 to $100 \%$. The field experiments on assessment of losses caused by cucurbit fruit fly in different cucurbits been reported 28.7 - 59.2, 24.7 - 40.0, 27.3 - 49.3, 19.4 - 22.1, and 0-26.2\% yield losses in pumpkin, bitter gourd, bottle gourd, cucumber, and sponge gourd, respectively. Considering 
previously reported, it is apparent that $>50 \%$ of the cucurbits are either partially or totally damaged by fruit flies and are unsuitable for human consumption (Table 1). The major insect- pests are reviewed and discussed in this manuscript Sources: [19].

Table 1: Major insect-pests of cucurbits with their potential yield losses.

\begin{tabular}{|c|c|c|c|}
\hline Serial No. & Name of the Pest & Distribution & Potential Yield Loss (\%) \\
\hline 1. & $\begin{array}{l}\text { Melon Fruit fly Bactrocera cucurbitae (Coquillett) } \\
\text { (Tephritidae, Diptera) }\end{array}$ & Throughout India & 30 to $100 \%$ \\
\hline 2. & $\begin{array}{l}\text { Red Pumpkin Beetle Aulacophora foveicollis (Lucas) } \\
\text { (Chrysomelidae, Coleoptera) }\end{array}$ & $\begin{array}{l}\text { Rajasthan, Tripura, Assam, Karnataka, } \\
\text { Uttar Pradesh, West Bengal }\end{array}$ & $35-75 \%$ \\
\hline 3. & $\begin{array}{l}\text { Hadda beetle Henosepilachna vigitioctopunctata Fab. } \\
\text { and Epilachna dodecastigma (Wied.) (Curculionidae: } \\
\text { Coleoptera) }\end{array}$ & $\begin{array}{l}\text { Eastern Uttar Pradesh and Bihar, Jammu, } \\
\text { Allahabad }\end{array}$ & More than $80 \%$ \\
\hline 4. & $\begin{array}{c}\text { Melon aphid Aphis gossypii Glover, Aphididae, } \\
\text { Hemiptera }\end{array}$ & $\begin{array}{c}\text { Andhra Pradesh, Assam, Delhi, Gujarat, } \\
\text { Haryana, Kerala, Karnataka, Tamil Nadu } \\
\text { etc. }\end{array}$ & Not available \\
\hline 5. & $\begin{array}{l}\text { Pumpkin caterpillar Diaphania indica (Saunders) } \\
\text { (Pyralidae, Lepidoptera) }\end{array}$ & Several states of India & $25-30 \%$ \\
\hline 6. & $\begin{array}{l}\text { Bottle gourd plume moth Sphenarches caffer (Zeller) } \\
\text { (Pterophoridae, Lepidoptera) }\end{array}$ & Varanasi, Tirupathi & Not available \\
\hline 7. & $\begin{array}{c}\text { Melon thrips Thrips palmi (Karny) (Thripidae, } \\
\text { Thysanoptera) }\end{array}$ & $\begin{array}{l}\text { West Bengal, Tamil Nadu, Andhra Pradesh, } \\
\text { Delhi, Jammu \& Kashmir, Uttar Pradesh etc. }\end{array}$ & $\begin{array}{l}\text { About } 80-90 \% \text { (mainly } \\
\text { in Cucumber) }\end{array}$ \\
\hline 8. & $\begin{array}{c}\text { White fly Bemisia tabaci (Gennadius) (Aleyrodidae, } \\
\text { Hemiptera) }\end{array}$ & $\begin{array}{c}\text { Almost throughout the India, excepting } \\
\text { very high altitude }\end{array}$ & Not available \\
\hline
\end{tabular}

\section{Melon Fruit Fly, Bactrocera Cucurbitae Coquillett}

Bactrocera cucurbitae is commonly known as melon fruit fly and it's originated from the Indo-Malayan region and adult fruit fly was introduced into Hawaii from Japan in 1895. The melon fruit fly is widely distributed from East Africa, USA, Taiwan, Japan, South China, northern Australia, South-east Asia and Indian sub-continent. Melon fruit fly is major pests of beans, melons, peppers, pumpkins, squashes, bitter gourd, cucumbers, edible gourds, eggplant, green beans, tomatoes and watermelon.
The female fruit flies puncture the soft and tender fruits with the help of hard ovipositor and lay eggs below the epidermis of the fruits. When hatching the maggots feed inside the pulp of fruits and infested fruits can be identified by the presence of brown resinous juice which oozes out from punctures fruit by flies ovipositor. These punctures have infected with various bacteria and fungi and result of this, the infested fruits start rotting, get distorted and malformed in shape and fallen fruit from plants pre-maturely [10,20] (Figure 1 \& 2).
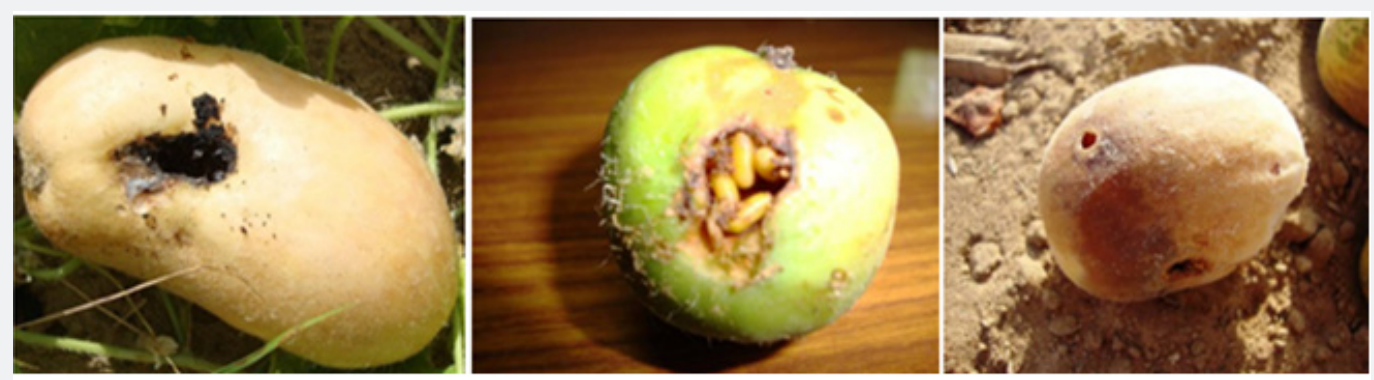

Figure 1

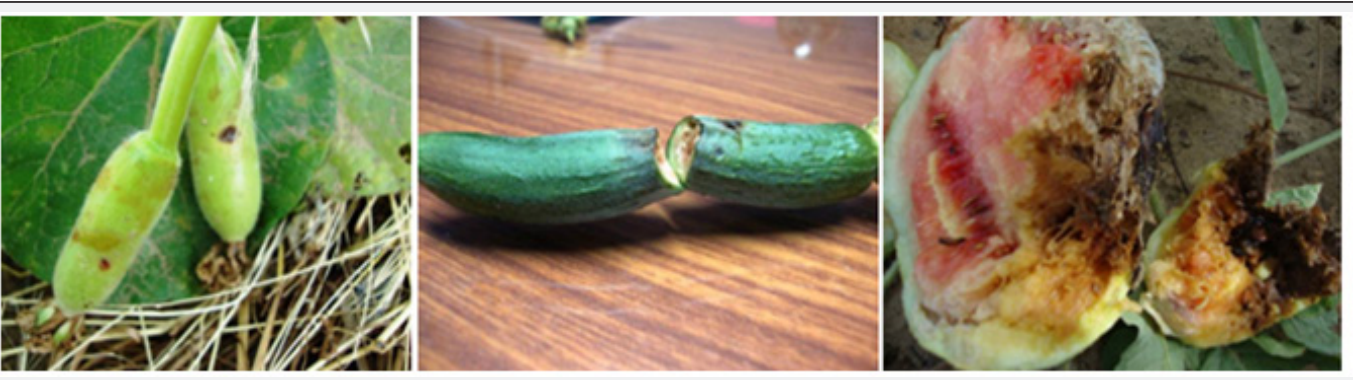

Figure 2 

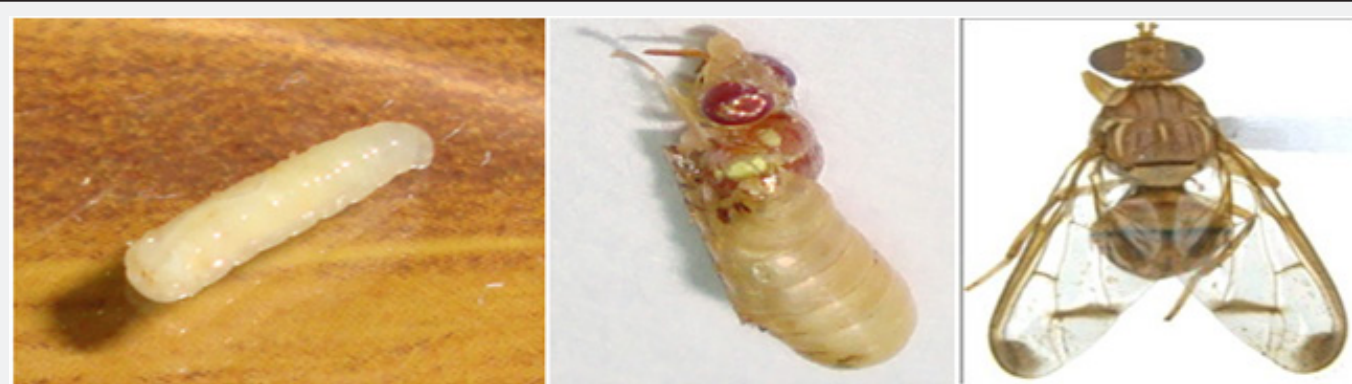

Figure 3

The female egg laying capacity is around 1,000 eggs. Eggs are laid in young fruit, but some time laid in the succulent stems of host plants. The sharp ovipositor of female is used for creating cavity for depositing eggs. The maggot period is 3 to 21 days depending on temperature and host. The full-grown maggot comes out from the fruit by making exit holes for pupation in the soil. The pupae are pupating in the soil at a depth of 0.5 to $15 \mathrm{~cm}$ and pupae survival depend on soil texture and moisture. Depending on temperature and the host, the pupal period may vary from 7 to 13 days. The pre-oviposition period of flies fed on cucumbers ranged between 11 to 12 days. Pre-oviposition and oviposition periods range between 10 to 16.3 , and 5 to 15 days, respectively, and the females live longer ( 21.7 to 32.7 days) than the males (15.0 to 28.5 days) [21] (Figure 3).
Hadda Beetle, Epilachna Vigintioctopunctata (Fabricius)

This species originated in the far east of Russia and has been expanding its range in the second half of the 20th century and is now found over most of Russia, North-East China, Northern Korea, Australia and Japan. It is found in different parts of South East Asia. The insect is considered to be one of the important pests of brinjal, sometimes becoming serious on cucurbits like snap melon, water melon, musk melon, ridge gourd etc. The grubs and adults are scraping the leaves of plant in a characteristic manner and feed on the epidermal layers of leaves which get skeletonized and gradually dry away. They affect the crop in all the stages [22] (Figure 4).
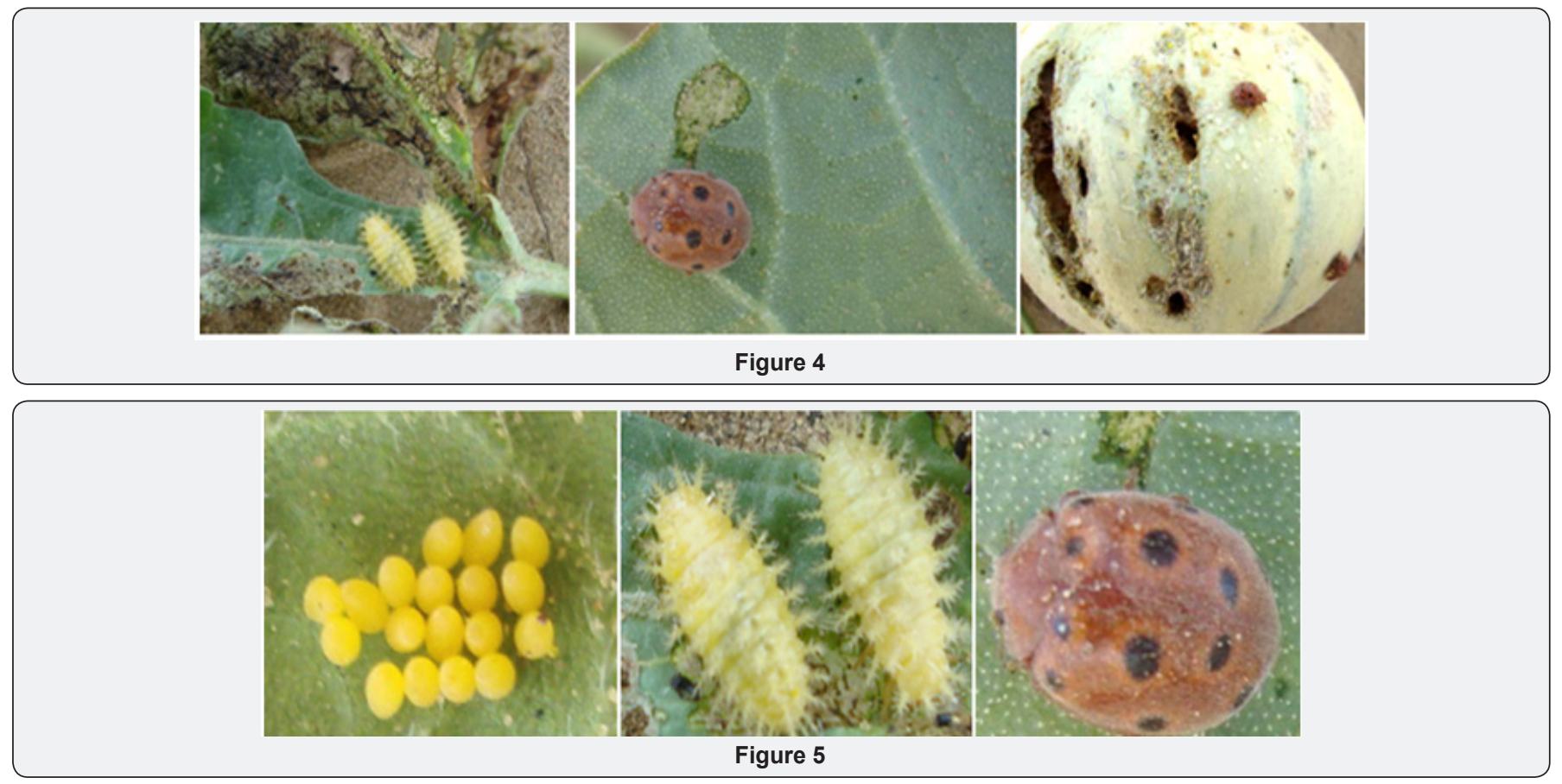

The gravid females laid $562.54+76.16$ eggs in several batches during the ovipositional period of $45.67+5.19$ days. Egg hatch ranged between 75.61-100 per cent. One female laid exceptionally high number of egg upto 1560. First instar larvae fed gregariously and they became non-gregarious from second instar onwards. The larvae scraped epidermal layer of leaves and sometimes skeletonised the entire leaf. However, [23] recorded incubation period of $5.20+0.87$, total larval period of $13.60+1.11$ and pupal duration of $4.10+0.54$. Individual pair copulated several times and single copulation lasted for 2-3 minutes. The pre-oviposition period ranged from 4-37 days. The longevity of male was 27 to 108 days (Av. 67.79+3.96 days) and that of females was 37 to 108 days (Figure 5). 


\section{Leaf Eating Caterpillar, Diaphania Indica (Saunders)}

The leaf eating caterpillar occurs in tropical and subtropical regions and it's native to southern Asia. It is occasionally a significant pest of cucurbits and also some other plants. The lead eating caterpillar attacks on cucurbits and eats their leaves of the plant. The cucurbits plants are watermelon, cucumber, melon, pumpkin and snake gourd etc. The caterpillars do the damage after hatching; they roll the leaves with silken threads and eat the leaves between the veins. They also attack the flowers and reduce the number of fruits set. Young fruits are also attacked by this pest. The caterpillars damage the skin and cause the fruits to rot [24] (Figure 6).
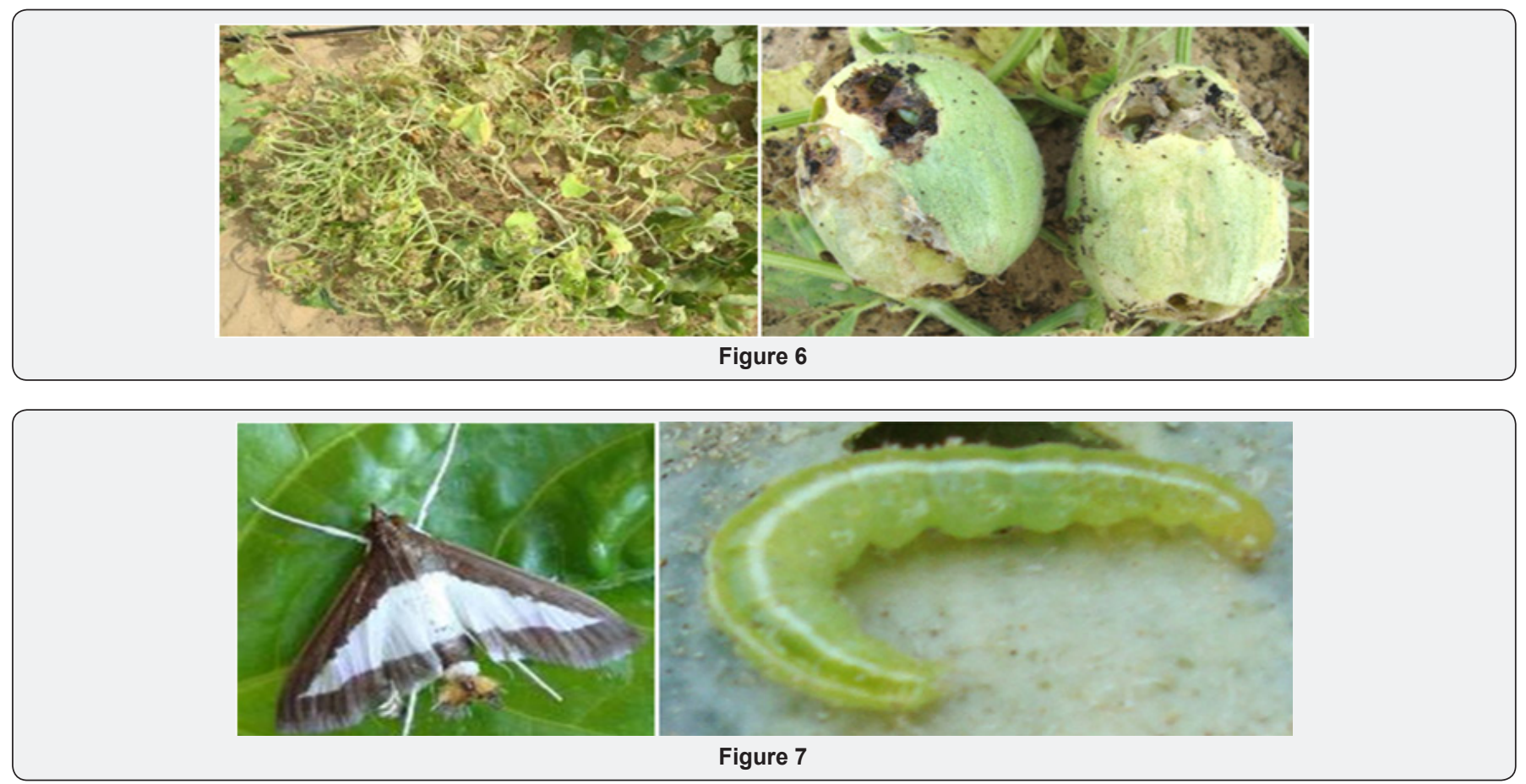

The eggs hatch and the caterpillars emerge. They are almost clear, but soon become green. Large caterpillars have two white lines along the back. When fully grown, they are about $20 \mathrm{~mm}$ long: some may be smaller, some larger. After a while, the caterpillars turn into pupae, green at first then brown. The pupae are in folds of the leaves. They are about $12 \mathrm{~mm}$ long and $3 \mathrm{~mm}$ wide. The adults hatch from the pupae after about 8-12 days. The adult is very obvious. The wings are white with a wide brown border. When the wings are spread, they are about $25 \mathrm{~mm}$ wide. At the end of the body is a group of hairs, rather like a brush. The females wiggle this brush, possibly to send out a chemical to attract the males. The life cycle from egg to adult is about 25 days $[25,26]$ (Figure 7).

\section{Melon Aphid, Aphis Gossypii Glover}

Melon aphid has a worldwide distribution. However it is a major pest of cotton and causes appreciable damage during severe drought conditions. It is a polyphagous pest and infests the cotton, cucurbits, brinjal, chilies andamaranthus. It is damage the tender shoots and the under surface of leaves in large numbers and suck the sap. Due to severe infestation of melon aphid results curling of leaves, stunted growth and gradual drying and death of young plants. Black sooty mould develops on the plant due to honey dew secretion of the aphids which falls on the lower leaves affecting photosynthetic activity of the plants [27] (Figure 8).

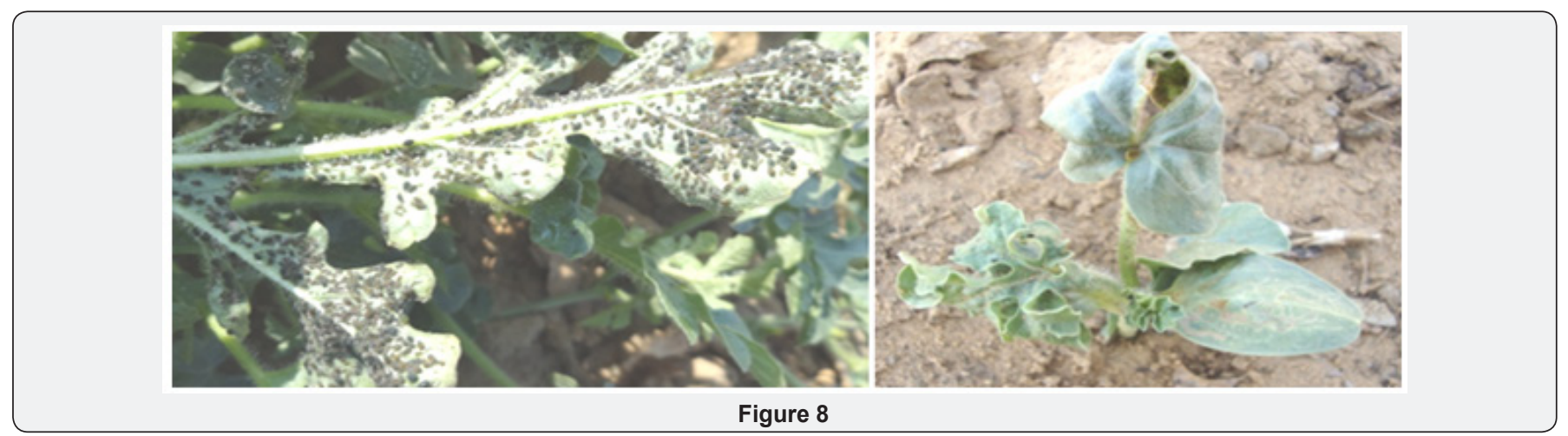




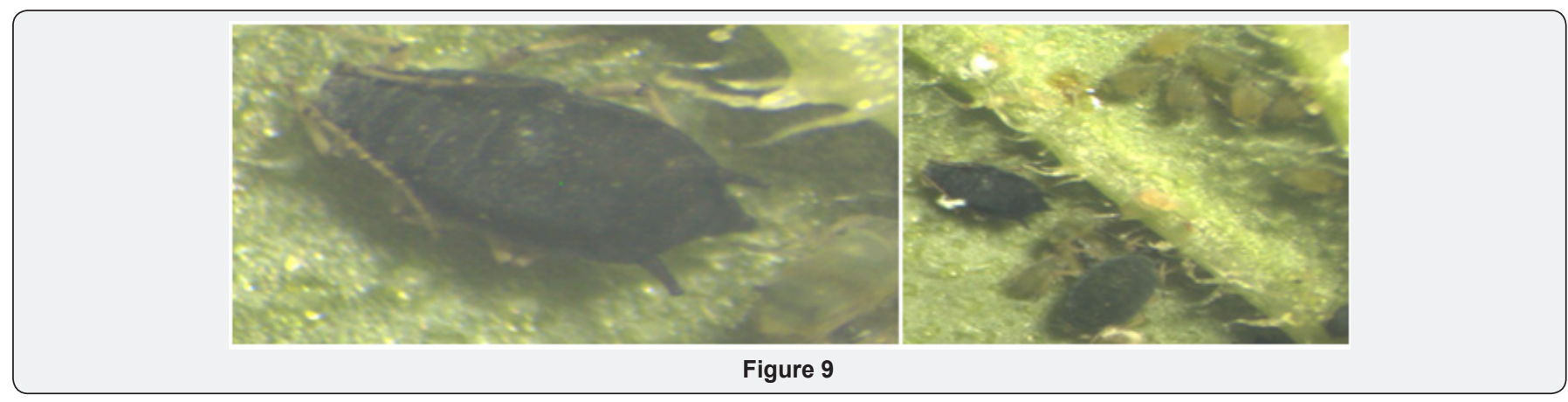

Incidence of A. gossypii was observed from last week of February to first week of April. Peak population was recorded in mid-March. Aphid population exhibited positive non-significant correlation with temperature whereas it exhibited significant negative correlation with minimum humidity and non-significant negative correlation with maximum humidity. The alate as well as apterous females multiply parthenogenetically and viviparously. The total nymphal period was $9.1 \pm 1.10$ days. The adult period was found to be $15.1 \pm 4.63$ days. Pre-reproductive, reproductive and post-reproductive periods were evaluated to be $2.7+0.82$, $16.3 \pm 3.97$ and $5.2 \pm 1.68$ days, respectively. The total life-span was recorded as $24.2 \pm 4.85$ days [28,29] (Figure 9).

\section{Whitefly, Bemisia Tabaci (Gennadius)}

White fly is distributed in all cotton growing regions of the world. It is infested about 50 different species of plants but it's a serious pest of cotton in certain regions of the country. The infestation of pest adversely affects the physiology of the plant at all stages of growth plant. It is a polyphagous pest like cucurbits, brinjal, chillies, potato, cotton and tomato. The nymphs of whitefly are found in large numbers on the under surface of leaves and sucking of sap. Due to severe infestation of white fly resulting premature defoliation, development of sooty mould on honey dew excreted, and shedding of flowers and fruits and bad flower opening [30,31] (Figure 10).
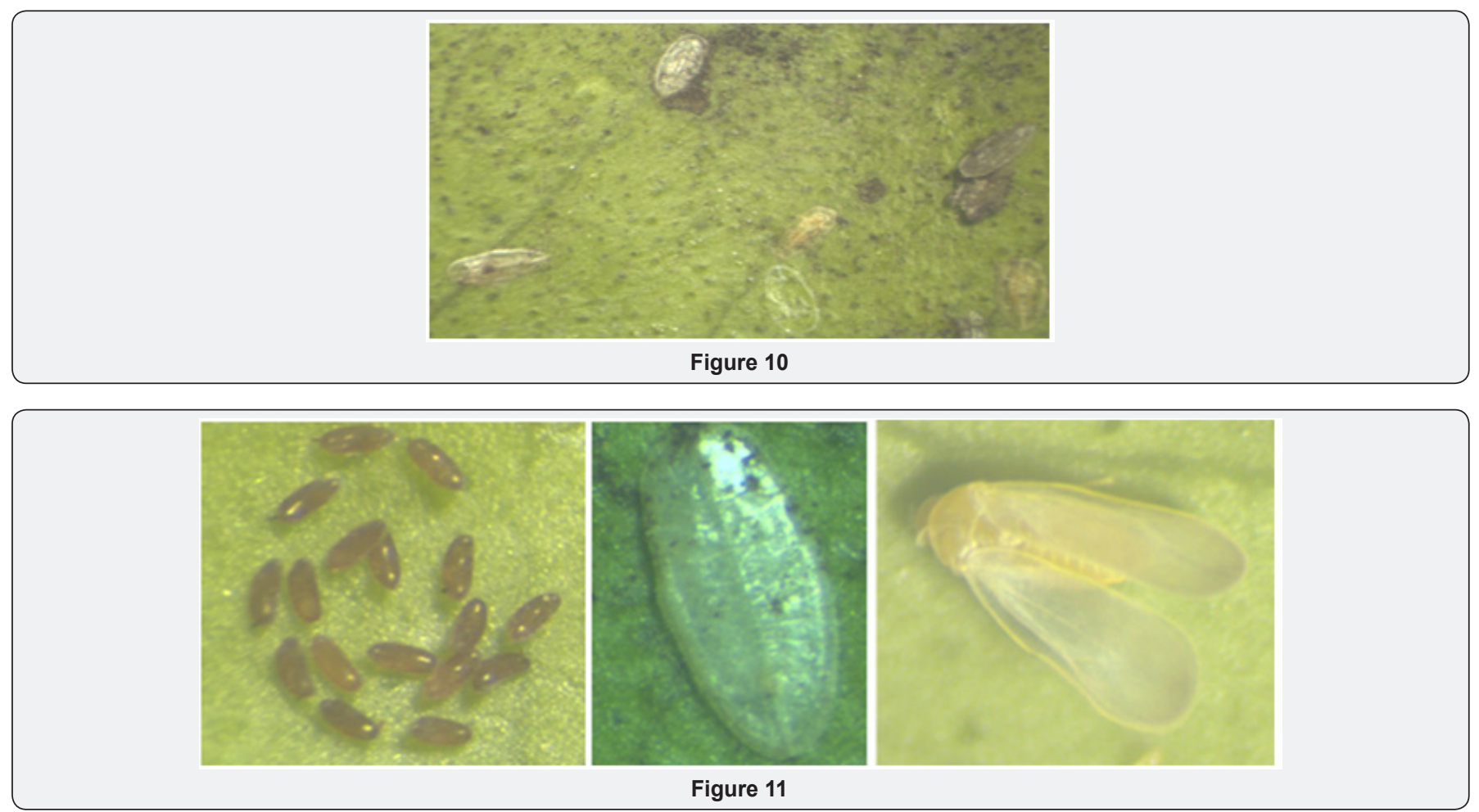

Eggs are laid usually in circular groups, on the undersides of leaves, with the broad end touching the surface and the long axis perpendicular to the leaf. They are anchored by a pedicel inserted into a fine slit made by the female. Each female lays up to 160 eggs. Hatching occurs after 5-9 days. The first instar or crawler is flat, oval and scale-like, and is the only mobile larval stage. It moves to feeding place on the lower surface of the leaf where it moulting occurs and becomes sessile stage in remaining nymphal stages. The first three nymphal stages completed last 2-4 days for each stages. The fourth nymphal stage is known as the puparium. Pupation take place about 6 days and within the latter period, the metamorphosis to adult occurs. The 
adult emerges from a rupture puparium and expands its wings before powdering itself with wax from glands on the abdomen. Copulation starts 12-20 hours after emergence and takes place several times throughout the life of adult whitefly. A female may live for 60 days, although the life of the male is generally much shorter, being between 9 to 17 days. Some 11 to 15 generations can occur within one year [32] (Figure 11).

\section{Beet Armyworm, Spodoptera Exigua Hubner}

The beet armyworm originated in Southeast Asia. It was first discovered in North America about 1876, when it was found in Oregon, and it reached Florida in 1924. For the first time, beet armyworm was observed on ridge gourd, Luffa acutangula in the hot arid region of north-western India, (i.e., Thar Desert) and identified as Spodoptera exigua. Beet armyworm is a polyphagous pest and serious pest of ridge gourd cause to leaves, flowers and fruits of plants. Seasonal activity varies considerably according to climate. In warm locations such as Florida, all stages can be found throughout the year, although development rate and overall abundance are reduced during the winter months [33]. The life cycle completed in around 24 days, and six generations have been completed during five months of summer weather in Florida [34]. Smaller larvae devour the parenchyma of leaves, so all that remains is the thin epidermis and veins. Larger larvae tend to burrow holes through thick areas of plants. Ridge gourd fruits are most susceptible to injury, starting from young fruit to maturity of fruits. The beet armyworm is damage to summer as well as rainy season but more incidences was recorded in the rainy season crop [12]. Tomato fruit is quite susceptible to cause injury, especially near fruit maturity, but beet armyworm is not considered as threatening to tomato as is the corn earworm, Helicoverpa zea [35]. In tomato crops, infestation early in the growing period is more damaging than later infestation, and as little as 1 caterpillar per 20 tomato plants can cause economic loss [36] (Figure 12).
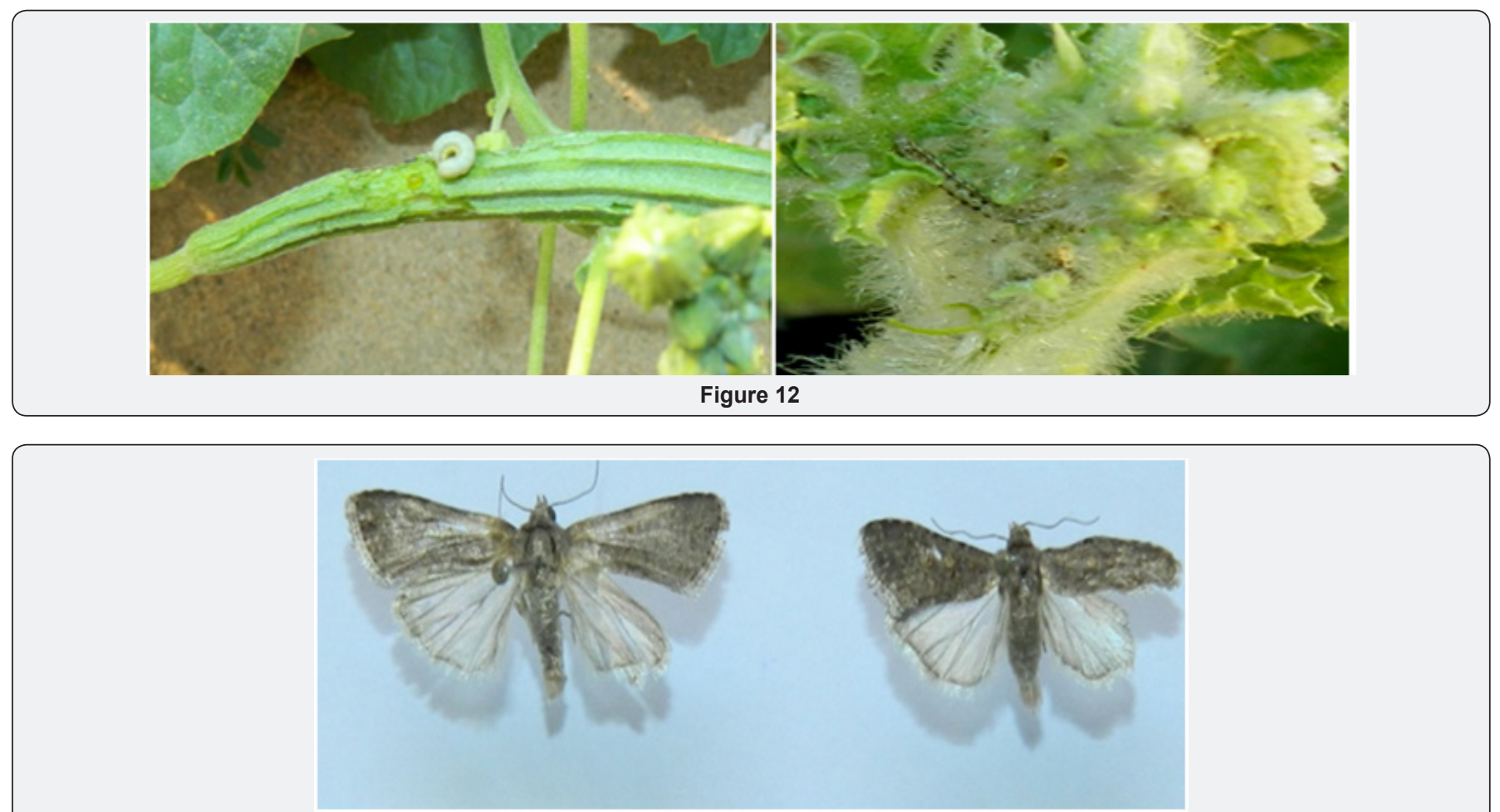

Figure 13

Eggs are laid in clusters of 50 to 150 eggs per mass. Eggs are deposited on the lower surface of the leaf, near blossoms and the tip of branch. The moth larvae are pale green or yellow in color during the first and second instars of the caterpillar, but third instar have pale stripes on body. The fourth instar larvae are darker dorsally and found dark lateral stripe. Larvae during the fifth instar are quite variable in appearance, tending to be green dorsally with pink or yellow color ventrally and a white stripe laterally. Pupation takes place in soil at the depth of 3 to $5 \mathrm{~cm}$. The moths are moderately sized, the wing span measuring 25 to $30 \mathrm{~mm}$. The forewings are mottled gray and brown, and normally with an irregular banding pattern and a light colored bean-shaped spot (Figure 13).

\section{Flower Beetles on Watermelon, Mylabris Macilenta,} Anthicus Crinitus and Anthrenus Subclaviger

Three flower beetles were observed on watermelon crop in the arid region of Rajasthan and identified as Mylabris macilenta, Anthicus crinitus and Anthrenus subclaviger. The average incidence of flower beetles on watermelon ranged between 1.07 to 5.13 per plant of M. macilenta, 3.33 to 7.60 per plant of A. crinitus and 2.87 to 8.60 per plant of A. subclaviger. The 
incidence and the numbers were higher in the months of (first fortnight of June) than during other months. Thus the highest mean number of these flower beetle species per plant were recorded in first fortnight of June $(5.13,7.60 \& 8.60$ per plant) and the lowest in second fortnight of April (1.07, 2.87\&3.33per plant) of M. macilenta, A. crinitus and A. subclaviger, respectively. The flower beetles were found to be aggregated on the flowers of the watermelon crop. They cause injury to the flowers, pollens, ovary of the crop. They appeared only as a casual feeder and their population was extremely low for affecting any appreciable damage on the plant. There is no previous record of M. macilenta, A. crinitus and A. subclaviger feeding on watermelon flowers [11]. The blister beetle, Mylabris macilenta was observed to cause serious damage to saffron flowers for the first time in Lahaul valley of Himachal Pradesh during 1993. The frequency of beetles was recorded to be $4.29+-0.72$ beetles on 10 saffron flowers per minute [37] (Figure 14).
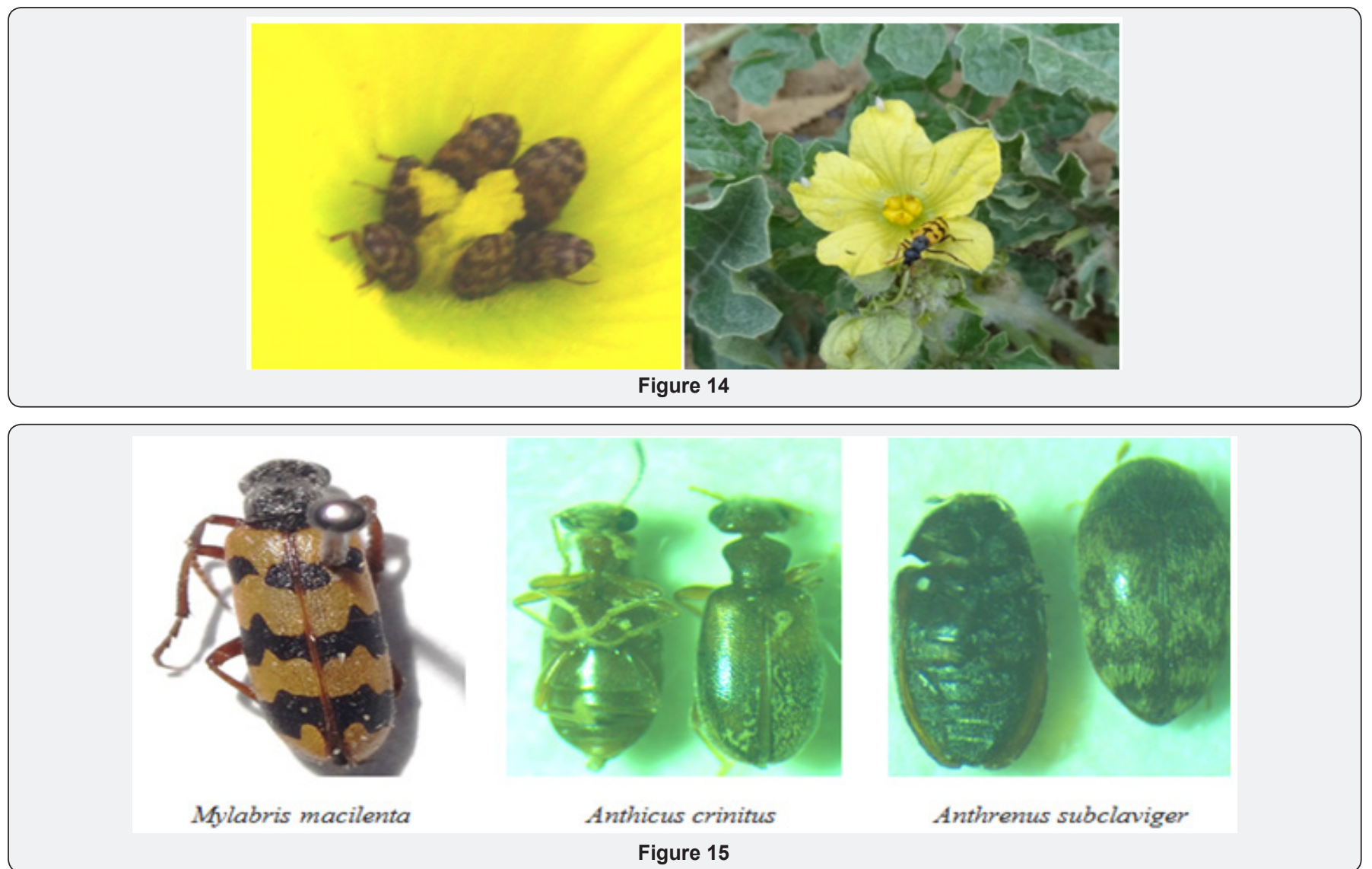

Flower beetle, M. macilenta is characterised as body uniformly black, except elytra which have brown-orange colouration largely extended everywhere with three zig-zag black trips. Head slightly longer than wide, head capsule subquadrate broadly curved posteriorly and subequal in length to the longitudinal length of eye. The measurement of adult is body length $15.56 \mathrm{~mm}$, body width $3.84 \mathrm{~mm}$, head length 3.01 $\mathrm{mm}$, head width $2.52 \mathrm{~mm}$, pronotum length $2.43 \mathrm{~mm}$, pronotum width $2.30 \mathrm{~mm}$, elytra length 9.91 , elytra width 3.84 and antenna length $3.13 \mathrm{~mm}$. A. crinitus is typically characterized as having body brown to dark brown and appendages somewhat paler but eyes dark. Pronotum is shiny with pubescence light brown and stout. The measurement of adult is body length $2.86 \mathrm{~mm}$, body width $0.67 \mathrm{~mm}$, head length $0.44 \mathrm{~mm}$, head width $0.56 \mathrm{~mm}$, pronotum length $0.50 \mathrm{~mm}$, pronotum width $0.48 \mathrm{~mm}$, elytra length $1.84 \mathrm{~mm}$, elytra width $0.96 \mathrm{~mm}$ and antenna length $0.94 \mathrm{~mm}$. A. subclaviger is morphologically characterised as having body small, darkish, typically about $2.55-2.68 \mathrm{~mm}$ long and have a generally round body form. Most have colourful body patterning produced by scales of yellow, browns and white. The head is small, kept hidden beneath the pronotum (=the plate that covers the upper part of the thorax). The antennae are clubbed, with the three apical antennal segments forming the club and the two basal segments also bulged. The measurement of adult is body length $2.61 \mathrm{~mm}$, body width $1.58 \mathrm{~mm}$, head length $0.17 \mathrm{~mm}$, head width $0.44 \mathrm{~mm}$, pronotum length $0.48 \mathrm{~mm}$, pronotum width $1.30 \mathrm{~mm}$, elytra length $2.22 \mathrm{~mm}$, elytra width 1.58 and antenna length $0.47 \mathrm{~mm}$ [11] (Figure 15).

\section{Acknowledgment}

The authors are thankful to Director, ICAR-Central Institute for Arid Horticulture, Bikaner, India, for providing facilities and advice required for experimentation, and to R. Swaminathan, Professor, Department of Entomology, MPUAT, Udaipur, India and Majeet Singh, Professor, SKRAU, Bikaner, India for critical discussion and suggestions. 


\section{References}

1. Choudhary BR, Haldhar SM, Maheshwari SK, Bhargava R (2016) Sources of variation in sponge gourd breeding. Journal of Agriculture Engineering and Food Technology 3(1): 58

2. Chakravarthy HL (1982) Cucurbitaceae. Fascicles of Flora of India, Howrah 11: pp.136.

3. Rai M, Singh M, Pandey S, Singh B, Yadav DS et al. (2007) IIVR: Fifteen Years of Accomplishments, Indian Institute of Vegetable Research Publication, Varanasi pp. 1-45.

4. Choudhary BR, Haldhar SM, Maheshwari SK, Bhargava R, Sharma SK (2015) AHMM/BR-8 (IC0599709; INGR 14043), a muskmelon (Cucumis melo L.) germplasm with monoecious sex form. Indian Journal of Plant Genetic Resources 28(3): 356-370.

5. Samadia DK, Haldhar SM (2017) Breeding strategies and scope of improvement in arid zone fruit crop plants under abiotic stressed agroclimate: an analysis. Journal of Agriculture and Ecology 4: 1-13.

6. Rahman AHMM, Anisuzzaman M, Ahmed F, Rafiul Islam AKM, Naderuzzaman ATM (2008) Study of Nutritive Value and Medicinal Uses of Cultivated Cucurbits. Journal of Applied Sciences Research 4(5): 555-558.

7. Choudhary BR, Haldhar SM, Maheshwari SK, Bhargava R, Sharma SK (2015) Phytochemicals and antioxidants in watermelon (Citrullus lanatus) genotypes under hot arid region. Indian Journal of Agricultural Sciences 85(3): 414-417.

8. Bhargava R, Gurjar K, Haldhar SM, Singh RS, Sharma BD (2016) Impact of water stress on photosynthesis and secondary metabolites in snap melon and musk melon. Indian Journal of Arid Horticulture 11: 30-35.

9. Muthusamy SK, Sivalingam PN, Sridhar J, Singh D, Haldhar SM (2017) Biotic stress inducible promoters in crop plants-a review. Journal of Agriculture and Ecology 4: 14-24.

10. Haldhar SM, Choudhary BR, Bhargava R, Sharma SK (2014) Development of an organic integrated pest management (IPM) module against insect-pests of muskmelon in arid region of Rajasthan, India Journal of Experimental Biology and Agriculture Science 2(1): 19-24.

11. Haldhar SM (2013) First record of the flower beetles, Mylabris macilenta, Anthicus crinitus and Anthrenus subclaviger in watermelon in arid region of Rajasthan. ICAR-CIAH News Letter pp.2-3.

12. Haldhar SM (2016) New report of beet armyworm, Spodoptera litura in ridge gourd (Luffa acutangula). ICAR-CIAH News Letter.

13. Haldhar SM, Bhargava R, Choudhary BR, Pal G, Kumar S (2013) Allelochemical resistance traits of muskmelon (Cucumis melo) against the fruit fly (Bactrocera cucurbitae) in a hot arid region of India. Phytoparasitica 41(4): 473-481.

14. Haldhar SM, Choudhary BR, Bhargava R, Sharma SK (2013) Screening of ridge gourd varieties/ genotypes (Luffa acutangula) for resistance fruit fly (Bactrocera cucurbitae) in hot arid region of Rajasthan. Indian Journal of Arid Horticulture 8 (1-2): 21-24

15. Haldhar SM, Choudhary BR, Bhargava R, Meena SR (2015) Antixenotic and allelochemical resistance traits of watermelon against Bactrocera cucurbitae in a hot arid region of India. Florida Entomologist 98(3): 827-834.

16. Haldhar SM, Choudhary BR, Bhargava R, Gurjar K (2015) Host plant resistance (HPR) traits of ridge gourd (Luffa acutangula (Roxb.) L. against melon fruit fly, (Bactrocera cucurbitae (Coquillett)) in hot arid region of India. Horticulturie Scientia 194: 168-174.

17. Haldhar SM, Samadia DK, Bhargava R, Singh D (2016) Screening of Snapmelon (Cucumis melo var. momordica) Genotypes for Resistance against Fruit fly (Bactrocera cucurbitae (Coquillett)) in Hot Arid Region of Rajasthan. International Journal of Horticulture, Canada 6(19): 1-7.
18. Haldhar SM, Samadia DK, Bhargava R, Singh D (2017) Host plant genotypes determine bottom-up effect of Cucumis melo var. callosus against melon fruit fly. Crop Protection 98: 157-165.

19. Bhowmik S, Saha S (2017) Study on the pest complex of bottle gourd in the gangetic plains of West Bengal. Journal of Entomology and Zoology Studies 5(2): 725-727.

20. Haldhar SM, Choudhary BR, Bhargava R (2015) Antixenotic resistance traits of muskmelon cucumis melo( 1.) against fruit fly (Bactrocera cucurbitae (coquillett)) in arid region of India. Indian Journal of Applied Entomology 29(2): 81-87.

21. Koul VK, Bhagat KC (1994) Biology of melon fruit fly, Bactrocera (Dacus) cucurbitae Coquillett (Diptera: Tephritidae) on bottle gourd. Pest Management and Economic Zoology 2: 123-125.

22. Tara JS, Sharma S (2017) Biology and life cycle of Henosepilachna vigitioctopunctata Fabricius, a serious defoliator of bitter gourd (Momordica charantia) in Jammu region (Jammu \& Kashmir) India. Indian Journal of Science Research 13(1): 199-203.

23. Kaur R, Mavi GS (2005) Biology of Epilachna vigintioctopunctata (Fabricius) (Coleoptera: Coccinellidae) on brinjal in Ludhiana, Punjab. Crop Research 29(1): 141-144.

24. Peter C, David BV (1991) Population dynamics of the pumpkin caterpillar, Diaphania indica Saunders (Lepidoptera: Pyralidae). International Journal of Pest Management 37(1): 75-79.

25. Kinjo K, Arakaki N (2002) Effect of temperature on development and reproductive characteristics of Diaphania indica Saunders (Lepidoptera: Pyralidae). Applied Entomology and Zoology 37: 141145 .

26. Nagaraju MC, Nadagouda S, Hosamani AC, Hurali S (2018) Studies on Biology of Cucumber Moth, Diaphania indica (Saunders) (Lepidoptera: Crambidae) on Bitter Gourd. International Journal of Current Microbiology and Applied Sciences 7: 4511-4516.

27. Chan CK, Forbes AR, Raworth DA (1991) Aphid-transmitted viruses and their vectors of the world. Research Branch, Agriculture Canada.

28. Pratap A (2011) Biology and breeding of food legumes. Indian Institute of Pulses Research pp. 432.

29. Bastianelli D, Grosjean F, Peyronnet C, Duparque M, Régnier JM (1998) Feeding value of pea (Pisum sativum L.) Chemical composition of different categories of pea. Animal Science 67: 609-619.

30. Sattar M, Sarwar M, Rahoo GM, Rizvi SNH (2004) Population Development of Whitefly, Bemisia tabaci (Gennadius) (Homoptera: Aleyrodidae) on Some Cucurbit Crops. Pakistan Journal of Zoology 36(4): 261-265.

31. Al-Shareef LAH (2011) Impact of whitefly, Bemisia tabaci (Gennadius) infestation on chlorophyl and carotene cocentrations, as well as moisture content in some vegetable plants in a greenhouse. Egyptien Journal of Experimental Biology 7(1): 11-15.

32. Shibuya T, Komouro J, Hirai NSY, Endo R, Kitaya Y (2010) Preference of sweet potato whitefly adults to cucumber seedlings grown under two different light sources. HorTechnology 20(5): 873-876.

33. Tingle FC, Mitchell ER (1977) Seasonal populations of armyworms and loopers at Hastings, Florida. Florida Entomologist 60(2): 115-122.

34. Wilson JW (1934) The asparagus caterpillar: its life history and control. Florida Agricultural Experiment Station Bulletin 271: 1-26.

35. Zalom FG, Wilson LT, Hoffmann MP (1986) Impact of feeding by tomato fruitworm, Heliothis zea (Boddie) (Lepidoptera: Noctuidae), and beet armyworm, Spodoptera exigua (Hübner) (Lepidoptera: Noctuidae), on processing tomato fruit quality. Journal of Economic Entomology 79(3): 822-826 
36. Taylor JE, Riley DG (2008) Artificial infestations of beet armyworm, Spodoptera exigua (Lepidoptera: Noctidae) used to estimate an economic injury level in tomato. Crop Protection 27(2): 268-274.
37. Chandel RS, Kumar J, Mehta PK (1996) Saffron, Crocus sativus Linn. A new host of blister beetle, Mylabris macilenta (Marshal) (Meloidae: Coleoptera). Journal of Insect Science 91: 79.

\section{Your next submission with Juniper Publishers will reach you the below assets}

- Quality Editorial service

- Swift Peer Review

- Reprints availability

- E-prints Service

- Manuscript Podcast for convenient understanding

- Global attainment for your research

- Manuscript accessibility in different formats ( Pdf, E-pub, Full Text, Audio)

- Unceasing customer service

Track the below URL for one-step submission https://juniperpublishers.com/online-submission.php 